\title{
TRADISI PEGI TEPAT MASYARAKAT DESA TALANG PETAI KABUPATEN MUKOMUKO DALAM PERSPEKTIF HUKUM ISLAM
}

\author{
Jamal Mirdad', Al Ikhlas² \\ 1Fakultas Syari'ah IAIN Batusangkar \\ e-mail: jamalmirdad@iainbatusangkar.ac.id \\ 2 Fakultas Agama Islam Universitas Negeri Padang \\ e-mail: alikhlas@fis.unp.ac.id
}

\begin{abstract}
Pilgrimage tradition in Indonesia is a phenomenon that has not been eradicated by the times. The more modern and sophisticated technology, the more pilgrims come. In each city and region there are many people who cult certain graves to the point that the tomb can solve their problems. The tradition of the grave pilgrimage or the term in Mukomuko Regency is "pegi tepat." It is a traditional practice carried out every year. Many practices that come from outside the teachings of Islam even there are deviations from the teachings of Islam itself such as: prostration on the grave, asking for healing, enliven the grave and combining between tradition and religion.
\end{abstract}

Kata kunci: tradisi, pegi tepat, Hukum Islam

\section{PENDAHULUAN}

$\mathcal{K}_{\text {masyarakat }}^{\text {earifan lokal yang ada dalam }}$ merupakan sebuah adat/tradisi yang sudah mengakar kuat dan berpengaruh terhadap kehidupan keseharian masyarakat setempat. Islam dengan ajarannya yang bersifat rahmatan lil 'alamin dan penuh toleransi memandang tradisi secara selektif. Tradisi akan senantiasa terpelihara dan dilestarikan selama sesuai dan tidak bertentangan dengan ajaran Islam. Bahkan tradisi/adat atau yang dikenal dengan istilah 'urf dapat menjadi salah satu dasar penetapan hukum. Tidak sedikit dari tradisi-tradisi yang berkembang bertentangan dengan Hukum Islam secara langsung maupun tidak langsung (Agung Setiyawan, 2012: 220).

Salah satu adat/tradisi yang masih mengakar kuat di tengah masyarakat adalah tradisi ziarah kubur. Ada beberapa istilah tradisi ziarah kubur yang digunakan oleh masyarakat, di Jawa misalnya dikenal dengan istilah nyekar yaitu diambil dari kata "sekar" yang bermakna bunga. Sedangkan di Sumatera Barat khususnya di Pariaman dikenal dengan istilah basapa yaitu suatu tradisi mengunjungi makam Syekh Burhanuddin Ulakan di Pariaman (Yosi Handayani, 2014) dan wilayah Mukomuko dikenal dengan istilah pegi tepat. Walaupun terdapat beberapa istilah, namun dalam penyebutan sehari-hari tetap menggunakan istilah ziarah kubur.

Umat Islam di Indonesia ada yang mengkultuskan kuburan menek moyang dan sosok yang dianggap saleh, untuk dijadikan perantara meminta berkah, kesehatan, meminta anak, jodoh, jabatan dan berbagai hajat lainnya. Masalah dikeramatkannya kuburan-kuburan 
bukan hanya di satu tempat saja, namun dalam jumlah yang sangat banyak. Dalam situs kaskus.us, Ireng kencana, disebutkan adala 51 tempat makam keramat dalam satu kecematan, itupun belum terdata secara keseluruhan karena tempat yang jauh dan ditengah hutan (Hartono Ahmad Jaiz, 2011: 1).

Praktek demikian sudah ada di beberapa penjuru dunia, Henri Chambert Loir menghubungkan antara penziarah dengan yang diziarahi dalam hal ini para wali atau orang yang mempunyai kekaromahan. Sang wali dalam berbagai manakibnya, menjadi pelaku-pelaku impian yang luar biasa dari masyarakat, dia melakukan perbuatan-perbuatan yang paling aneh, paling tak beralasan, bahkan paling tidak masuk akal, dia mewujudkan hasrat tak terhingga untuk melepaskan diri dari segala bentuk permasalahan duaniawi. Sehingga makam-makan itu dijadikan tempat pengungkapan semua dambaan hatinya (Henri Chambert Loir dan Claude Guilttot, 2010: 5).

Tujuan para peziarah mendatangi makam tersebut sangat beragam, ada yang karena ingin dimudahkan dalam segala urusan, mohon keselamatan, keberkahan, kesuksesan, kesembuhan dari suatu penyakit, keinginan segera menemukan jodoh, berharap mendapat rezeki melimpah, minta laris usaha perdagangan/ bisnis, ingin terbebas dari mara bahaya, atau karena ketaatan mengingat akan kematian dan mengenang para alim ulama sekaligus kirim do'a dan lainnya. Semuanya atas dasar kepercayaan dan keyakinan terhadap kekeramatan makam tersebut.

Di Desa Talang Petai ziarah kubur dikenal dengan istilah Pegi Tepat. Tradisi ini dilakukan untuk menziarahi kuburan nenek moyang mereka. Pegi yang berarti pergi atau mengunjungi, sedangkan tepat merupakan salah satu lokasi makam nenek moyang mereka yang dianggap keramat. Tradisi Pegi Tepat menjadi upacara rutinitas masyarakat Talang Petai setiap tahunnya, adapaun kuburan yang dikunjungi adalah kuburan nenek moyang mereka yang dianggap memiliki kesaktian tinggi dan telah berjasa membangun desa tersebut.

Pada tradisi Pegi Tepat terindikasi keyakinan keimanan para peziarah masih ambivalen, campur aduk, dan tidak murni. Satu sisi menyatakan ketauhidannya secara mutlak akan tetapi di sisi lain menyimpan kepercayaankepercayaan tertentu terhadap makammakam yang dianggap keramat tersebut. Persoalannya kemudian adalah apabila ziarah ke makam-makam yang diyakini masyarakat luas sebagai tempat-tempat keramat, maka niat bisa jadi tetap berada pada garis yang lurus, atau mungkin juga telah terjadi penyimpangan sehingga dapat membahayakan kemurnian tauhid para peziarah karena dalam ritualnya terjadi tumpang tindih antara hal-hal yang berasal dari agama dan dari tradisi atau bahkan telah jatuh dalam praktek kemusyrikan (Subri, 2017: 4).

Dalam penelitian ini, penulis mengungkap tentang fakta dari tradisi Pegi Tepat yang telah lama berlaku pada masyarakat Desa Talang Petai. Peneliti kemudian memberikan penilaian atau pandangan sebagai hasil dari penelitian berdasarkan kepada perspektif hukum Islam. 


\section{METODE PENELITIAN}

Penelitian ini bersifat kualitatif dengan mencakup pengumpulan data dan analisis data. Teknik pengumpulan data menggunakan participant observation dan uncontrolled observation. Kemudian ditambah dengan wawancara mendalam (interview), dilakukan kepada pelaku dan penyelengggara tradisi Pegi Tepat, dan sumber lain dengan pertimbangan sumber tersebut dapat memberikan informasi yang valid.

\section{PEMBAHASAN}

\section{A.Ziarah Kubur dalam Pandangan Hukum Islam}

Ziarah Kubur di Dunia Islam telah tumbuh dan mengakar dalam rentang sejarah yang cukup lama yaitu sudah ada semenjak praIslam, hal ini ditandai dengan adanya permohonan kepada arwah nenek moyang mereka yang telah meninggal dunia. Praktek yang demikian juga ditemukan di berbagai belahan dunia. Pada masa Arab jahiliyah, mereka mempunyai tradisi menyembah, menganggungkan berhala dan arwah nenek moyang mereka. Mereka beranggapan bahwa arwah tersebut mempunyai kendali dan kekuatan atas permohonan orangorang yang masih hidup. Sehingga budaya mengagungkan leluhur berakar kuat di Arab Jahiliyah (M. Misbahul Mujib, 2016) Tradisi ini berlanjut ke periode pertama Islam kemudian berkembang seiring dengan adanya perkembangan kebudayaan Islam yang rentan terhadap pengaruh-pengaruh di luar Islam. Praktek ziarah kubur tercatat beberapa kali perubahan, menurut Ahmad Taufiq Hidayat, ada beberapa kali bentuk perubahan hukum ziarah kubur tersebut yaitu:

1. Nabi memperbolehkan Umat Islam melakukan ziarah kubur ini terjadi pada masa paroh pertama periode Makkah.

2. Nabi melarang praktek ziarah kubur karena mempertimbangkan masih lemahnya kekuatan iman kaum muslim ketika itu, sehingga Nabi mencemaskan akan rusak aqidah umat Islam. Selain dari itu, makammakam yang diziarahi kebanyakan makam orang-orang musyrik dan para penyembah berhala, dan Islam memutuskan hubungan dan keterikatan dengan mereka, ini terjadi pada paroh kedua periode Makkah.

3. Nabi memperbolehkan lagi untuk berziarah ke kuburan dengan situasi yang ada, yaitu umat Islam sudah mempunyai keimanan yang kuat dan tidak mudah dirusak oleh paham-paham yang di luar Islam, ini terjadi pada periode Madinah (Ahmad Taufik Hidayat, 2013: 29).

Sebelum adanya larangan melakukan ziarah kubur, Nabi memperbolehkan siapa saja kaum muslimin untuk melakukannya, namun Nabi khawatir akan keimanan kaum muslimin ketika itu, karena aqidah mereka masih rapuh, untuk itulah Nabi melarangnya. Namun, dari beberapa sumber lainnya, tidak ditemukannya dasar yang kuat dalam menegaskan boleh melakukan ziarah kubur pada periode awal Islam sebelum adanya 
larangan dari Nabi Muhammad Saw sendiri.

Hal tersebut ditegaskan oleh Imam al-Nawawi dalam kitab al Majmuu' (V/310) yang dikutip oleh alAlbani, larangan ziarah kubur pertama kali itu disebabkan oleh kedekatan masa mereka dengan masa jahiliyah. Barangkali mereka dapat mengeluarkan ucapan-ucapan orang jahiliyah yang bathil. Setelah kaidah-kaidah Islam berdiri tegak dan hukumhukumnya pun sudah berjalan normal, maka ziarah kubur diperbolehkan kembali. Akan tetapi, Rasulullah memberikan penekanan melalui sabda beliau, "Janganlah kalian berkata-kata bathil" (Muhammad Nashruddin Albani, 2005: 406).

Kebolehan untuk berziarah kubur dan bahkan dianjrukan oleh Rasulullah Saw dijelaskan dalam hadis beliau:

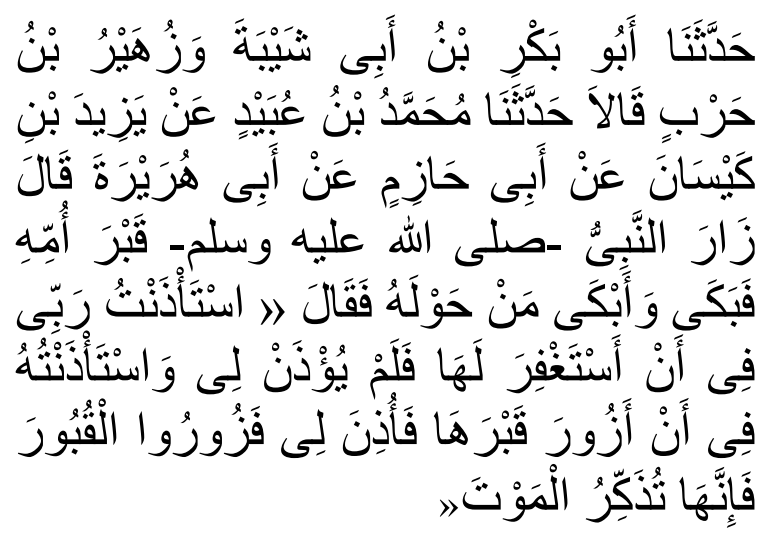

"Dari Abu Bakr bin Abi Syaibah dan Zuhair bin Harb, mereka berdua berkata: Muhammad Bin 'Ubaid menuturkan kepada kami: Dari Yaziid bin Kasyaan, ia berkata: Dari Abu Haazim, ia berkata: Dari Abu Hurairah, ia berkata: Rasulullah Shallallahu'alaihi Wasallam berziarah kepada makam ibunya, lalu beliau menangis, kemudian menangis pula lah orang-orang di sekitar beliau.
Beliau lalu bersabda: "Aku meminta izin kepada Rabb-ku untuk memintakan ampunan bagi ibuku, namun aku tidak diizinkan melakukannya. Maka aku pun meminta izin untuk menziarahi kuburnya, aku pun diizinkan. Berziarahkuburlah, karena ia dapat mengingatkan engkau akan kematian" (HR. Muslim)

Dari hadis di atas dapat dipahami bahwa ziarah kubur merupakan bagian dari syari`at Islam. Artinya ziarah kubur bukanlah sesuatu yang terlarang. Sebab pada ziarah kubur tersebut terdapat pelajaran bagi setiap orang yang melakukannya, yaitu mengingatkan mereka pada kematian. Orang yang senantiasa mengingat akan kematian tidak akan terlena dengan gemerlap duniawi dan ia akan senantiasa mempersiapkan diri untuk kematian tersebut.

\section{B. Praktek dan Pemaknaan Tradisi Pegi Tepat Masyarakat Talang Petai Kabupaten Mukomuko}

Maraknya Ziarah kubur akhirakhir ini disebabkan dalam kehidupan yang dijalani banyak orang berhadapan dengan berbagai masalah pelik yang menjadikan rasionalitas mereka tidak berdaya, sehingga menimbulkan kecemasan, ketakutan dan ketidaktenangan. Dalam situasi seperti ini, sebagian dari mereka bahkan ada yang kalap, melakukan tindakan yang tidak semestinya, untuk menyelesaikan permasalahan tersebut salah satu caranya adalah dengan berziarah. Spiritual ziarah diyakini dapat menenangkan jiwa, karena dalamnya terdapat hal-hal yang mendatangkan ketenangan, seperti dzikrullah dalam 
bentuk bacaan tahlil, tahmid dan tasbih (Purwadi dkk, 2006: 25).

Tradisi Pegi Tepat merupakan ziarah masyarakat Talang Petai ke makam Datuk Bandaro Sutan Malin Sati atau yang lebih dikenal masyarakat dengan sebutan Puyang Muaro Danau. Tradisi ini dilakukan untuk penghormatan, kemuliaan dan kesaktiannya yang dituju kepada tokoh tersebut, karena ia telah berjasa mendirikan perkampungan serta melindungi masyarakat. Masyarakat beranggapan bahwa tokoh tersebut merupakan sosok seseorang yang patut dihormati mengingat jasanya kepada perkampungan yang mereka huni sekarang ini. Hal yang demikian, sanada yang diungkapkan oleh Purwadi, dilihat dari konteks orang yang diziarahi bahwasanya fenomena ziarah kubur hari ini meliputi dua aspek, salah satunya ialah ziarah kepada tokoh yang dianggap mempunyai jasa besar dalam kehidupan mereka, seperti pahlawan, raja, dan ilmuan. Hal ini menunjukkan bahwa ziarah bukan hanya panggilan agama, tapi juga panggilan kemanusiaan (Purwadi dkk, 2006: 3).

Dalam konteks meneladani perjuangan orang yang diziarahi, paling tdak ada dua fenomena yang dapat disaksikan sampai hari ini. Pertama, ziarah kepada tokoh yang dianggap mempunyai jasa besar dalam kehidupan mereka, seperti pahlawan, raja, dan ilmuan. Hal ini menunjukkan bahwa ziarah bukan hanya panggilan agama, tapi juga panggilan kemanusiaan. Kedua, ziarah kepada tokoh agama, nabi, sahabat dan wali.
Fenomena kedua ini bermotif ganda, disamping mengenang perjuangan mereka, juga ada motif mencari barkah dari Allah melalui doanya para wali. Dalam agama, hal ini dikenal dengan istilah wasilah atau tawassul.

Dalam al Quran kata al wasilah ini ditemukan di dua tempat, yaitu Surat Al- Maidah ayat 35 dan al Isra' ayat 57:

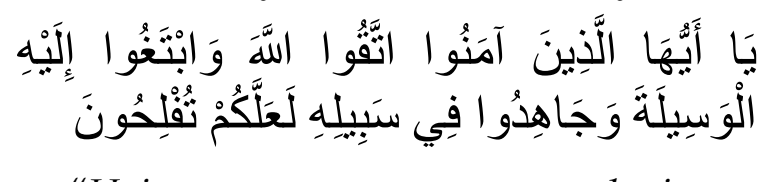

"Hai orang-orang yang beriman, bertakwalah kepada Allah dan carilah jalan yang mendekatkan diri kepadaNya, dan berjihadlah pada jalan-Nya, supaya kamu mendapat keberuntungan (Q.S. Al Maidah [5]: 35).

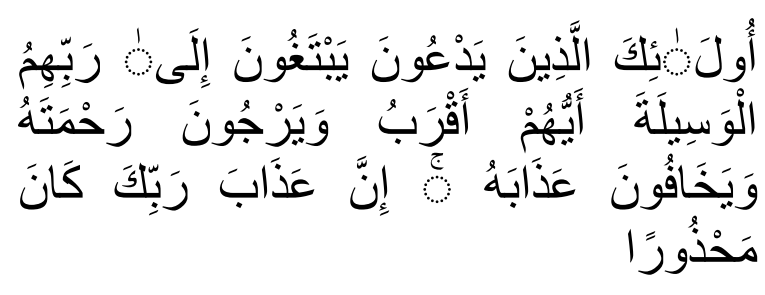

"Orang-orang yang mereka seru itu, mereka sendiri mencari jalan kepada Tuhan mereka siapa di antara mereka yang lebih dekat (kepada Allah) dan mengharapkan rahmat-Nya dan takut akan azab-Nya; sesungguhnya azab Tuhanmu adalah suatu yang (harus) ditakuti.Sampai saat ini, pandangan umat Islam tentang tawassul kepada para wali, terutama ulama besar yang termasuk dalam kelompok wali songo, masih belum mencapai kata sepakat. Sebagian menganggapnya tidak masalah, sebagian kalangan lain menganggap kunjungan ini bisa merusak aqidah, terutama akibat terpesona "secara berlebihan" oleh 
karomah yang dimiliki para kekasih Allah tersebut" (Q.S. Al Isra [17]: 57).

Fenomena Pegi Tepat di masyarakat Talang Petai, memposisikan Puyang Muaro Danau bukan hanya orang yang berhasil membangun perkampungan saja, akan tetapi ia dianggap juga memiliki kesaktian yang luar biasa. Bahkan setelah ia meninggal ia dianggap masih menjaga anak cucunya dengan cara mengingat akan dirinya dengan menziarahi makamnya. Pada masa Puyang Muaro Danau masih hidup, ia memiliki kesaktian yang cukup tinggi, ia selalu menolong dan melindungi masyarakatnya dari berbagai ancaman. Ketika merasa akan terjadi sesuatu yang buruk, ia selalu memberi tahu kepada masyarakat untuk tetap hatihati dan segera mencari tempat berlindung. Pada masa itu masyarakat Talang Petai pernah terancam oleh binatang buas yang berkeliaran di tengah desa sehingga masyarakat tidak ada yang berani keluar rumah, berkat kesaktian Puyang Muaro Danau, ia dapat mengatasi ancaman tersebut.

Selain dari itu, masyarakat pernah dilanda wabah penyakit begitu berbahaya dan banyak memakan korban, Dengan kesaktian yang dimiliki oleh Puyang Muaro Danau ia berhasil mengobati warganya dengan menggunakan asam dan kemenyan yang dibakarnya. Sehingga sampai sekarang dalam acara penutup dari serangkaian acara Pegi Tepat ini yaitu acara tolak bala selalu menggunakan asam sebagai bahan obat. Sepeninggalan Puyang Muaro Danau ini, banyaklah masyarakat mengunjungi makamnya dan menurut kepercayaan masyarkat, Puyang Muaro Danau ini masih bisa menjaga masyarkat dengan syarat setiap tahun wajib dikunjungi, kalau tidak, akan ada musibah besar yang akan menimpa seluruh masyarakat (Tipe, 2017).

Tradisi Pegi Tepat ini pada awalnya dilakukan setelah panen padi secara bersama. Namun seiring dengan perkembangan yang terjadi, dan sesuai dengan kondisi alam lingkungannya, disepakatilah oleh masyarakat Talang Petai supaya tradisi ini tetap dilestarikan. Oleh sebab itu, supaya acara ini bisa diikuti oleh semua masyarakat, maka acara ini dilakukan setiap setelah lebaran Idul Fitri dan menjelang Idul Adha. Hingga sampai sekarang acara ini tetap dilaksanakan sebelum hari raya Idul Adha setiap tahunnya.

Acara Tradisi Pegi Tepat ini tidak hanya sekedar berkunjung kemakam saja, namun masyarakat membuat serangkaian acara sampai memasak dan makan bersama disekitar lokasi, sehingga disekitar lokasi tersebut selayaknya menjadi acara besar yang dihadiri oleh seluruh masyarakat dari berbagai kalangan baik itu dari kalangan adat, Syara', pemerintahan Desa dan masyarakat dari berbagai latar belakang. Selain itu, yang menjadi sorotan yaitu masyarakat yang datang, sebagian dari mereka bersujud di makam tersebut, baik anak-anak, maupun orang dewasa. Hal ini masih jadi perdebatan ditengah masyarakat, apakah perbuatan tersebut dibenarkan atau tidak. Namun menurut kepercayaan masyarakat setempat meyakini apabila sujud dimakam tersebut diperbolehkan asalkan tidak membaca selayaknya membaca doa ketika ketika shalat (sujud). 
Adapun beberapa perlengkapan penting dalam melaksanakan acara tradisi pegi tepat ini di antaranya adalah:

a. Cerano, cerano ini merupakan perlengkapan untuk syara', adat dan makam. Dengan demikian, para penziarah membutuhkan tiga cerano masing-masing untuk kaum adat, syara' dan untuk diletakkan di makam. Carano yang berada di makam digunakan sebagai tempat uang jika masyarakat ada yang bernazar.

b. Air yang dimasuk dalam botol, tujuanya untuk alat peminta obat supaya diberi kesembuhan oleh Allah Swt melalui perantara arwah nenek moyang mereka, biasanya diletakkan disamping carano.

c. Kain putih, kain putih ini digunakan untuk menutup seluruh makam Datuk Bandaro, dengan tujuan supaya apapun yang terjadi di sekitar kuburan tidak terlihat oleh para penziarah.

d. Dulang beserta cungkupnya (penutup). Dulang ini hanya Satok yang membawanya yang digunakan untuk tempat menyimpan jamba satok yang dipakai untuk acara mendoa nantinya.

e. Kemenyan dan wadahnya, disaat mendoa juga dibutuhkan kemenyan beserta wadah untuk alas bara api tersebut.

f. Satu ekor ayam, untuk masingmasing keluarga.

g. Perlengkapan lainnya ialah hasil masakan masyarakat perkeluarga yang dimasak di lokasi tepat atau makam (Pedawani, 2015: 63).
Dalam acara Pegi Tepat ini adapun serentetan acaranya ialah yang paling pertama yaitu memasang kain putih di makam dan melakukan Cucua Aia (memberi tahu atas kedatangan anak cucunya) yaitu dengan membaca shalawat Nabi 3 kali sambil menyiram air di atas kuburan. Setelah selesai сисиа aia barulah berziarah dengan membaca surat al-ikhlas 100 kali, yang dilakukan oleh dukun neghi. Dukun neghi adalah seseorang yang dipercaya oleh masyarakat setempat mempunyai kemampuan dalam bidang supranatural, seperti menolak berbagai penyakit, menyembuhkan penyakit, menghindarkan bencana dan lainnya (Eny Christyawaty, 2011: 93). Dukun neghi ditemani oleh satok yaitu orang yang merawat barang-barang peniggalan Datuk Bandaro Sutan Malin Sati, Kemudian setelah semuanya datang barulah turun perintah dari dukun neghi kepada kepala kaum untuk mulai menyembelih ayam di sekitar lokasi makam yang diziarahi.

Dalam hal konteks penggunaan air sebagai salah satu alat upacara tradisi pegi tepat, setidaknya ada dua bentuk air, yaitu сисиа aia dan air "keramat" yaitu air yang dapat menyembuhkan berbagai macam penyakit. Penggunaan air sebagai salah satu alat dalam ziarah kubur juga terdapat di wilayah Jawa dalam acara "nyekar ke makam Sunan Muria". Dalam acara nyekar dikenal dengan istilah "air suci" atau "air tiga rasa", banyak orang yang datang untuk mengambil air itu sebagai obat atau kepentingan lainnya. Banyak juga 
paranormal memanfaatkan air tersebut untuk penyembuhan. Sebagian peziarah mempercayai bahwa dengan meminum air itu jiwa mereka menjadi lebih tenang, rasa pecaya diri mereka lebih tebal dan badan menjadi lebih sehat. Air suci atau air "keramat" merupakan refleksi pemikiran masyarakat terhadap kesucian air zam-zam di Makkah, sehingga setiap mengunjungi makam orang yang karomah akan ada air suci atau air "keramat" yang merupakan hasil kekaromahan seorang tokoh tersebut (Ahmad Falah, 2012: 34).

Menurut kepercayaan masyarakat Desa Talang Petai Mukomuko, semua kegiatan atau pekerjaan di tepat ini satok lah yang mesti lebih didahulukan. Apabila ada salah satu pekerjaan yang mendahului satok maka akan terjadi sesuatu yang buruk di lokasi tepat ini, contohnya saja ada gulai yang sudah siap lebih dahulu dari pada gulai satok, dan kemudian ada yang memakannya sebelum gulai itu dipisahkan untuk acara mendoa nantinya, maka akan terjadi musibah kepada keluarga orang tersebut selain itu biasanya juga turun hujan saat acara di tepat ini. Itu lah salah satu bentuk aturan yang mesti dijalani oleh masyarakat Talang Petai selama acara Pegi Tepat ini berlangsung.

Selesai menyembelih dan membersihkan ayam barulah pegawai syarak dan pegawai adat serta orang banyak duduk berkumpul di lapangan lokasi mendoa yang terdapat disekitar tepat, untuk bermufakat menentukan hari tolak bala atau mendoa di tengah padang (dusun), setelah harinya diputuskan oleh kaum syarak dan adat, maka acara selanjutnya adalah tahlil untuk mendoakan nenek moyang mereka (Datuk Bandaro Sutan Malin Sati). Tahlilan ini terbagi atas dua yaitu, pertama tahlil fadiah (menghadiahkan tahlil), kedua tahlil mamitak (jika ada anak cucunya yang bernazar, misalnya anak cucunya bertanam jagung, maka ia bernazar kalau jagungnya berhasil semua dan lebih banyak dari pada biasanya maka waktu orang Pegi Tepat nanti saya tahlil disana) ataupun bernazar dalam hal-hal lain seperti selamat dari suatu musibah maupun sembuh dari penyakit dan yang lainnya (Abu Jamar: 2017).

Setelah melakukan tahlilan, turun perintah dari dukun kepada kepala kaum untuk menyuruh anak kemenakannya mulai mengangkut jamba kelapangan mendoa yang dimulai dari jamba besar yang pakai dulang (jamba satok), dan jamba inipun disusun berdasarkan kedudukan pemiliknya dalam tatanan adat istiadat dan pangkat dalam kepengurusan desa. Jamba yang paling ujung dalam lintasan lapangan mendoa adalah jamba satok, jamba dukun neghi dan jamba kepala desa, setelah itu diikuti oleh jamba pengurus adat dan syarak serta perangkat desa. Setelah itu barulah diikuti oleh jamba masyarakat biasa. Sedangkan jamba para mantan pegawai syarak dan pegawai adat maupun mantan imam, khatib, gharin, kepala desa atau yang lainnya disusun di luar lapangan atau luar dari pagar lintasan untuk tempat mendoa, tepatnya di belakang atau di atas dari jamba satok (Kalam: 2017). Kalau dilihat dari segi cara penyusunan jambanya, tampak bahwa masyarakat Talang Petai ini masih menerapkan sistem tingkatan-tingkatan sehingga terkesan 
membeda antara masayarakat biasa dengan orang-orang yang memiliki kedudukan dalam kepengurusan desa dalam hal-hal tertentu. Tetapi dalam kesehariannya semua masyarakat dipandang sama, ketika semua jamba tersusun rapi dan orang-orang sudah duduk dengan rapi barulah acara mendoa bersama dilakukan

Hari berikutnya acara malimau pusako (membersihkan) barang-barang peniggalan dari Datuk Bandaro Sutan Malin Sati yang berupa pedang, parang, pasu, dulang dan gong, yang bertempat di rumah satok. Acara malimau ini dilakukan oleh dukun negeri yang sekaligus mempersiapkan keperluan untuk acara tolak bala. Adapun yang disiapkan oleh dukun negeri ialah limau lunggo yang sudah disediakan oleh keluarga satok, biasanya limau ini sebanyak satu sampai tujuh buah yang pastinya berjumlah ganjil. Limau ini yang digunakan untuk membersihkan pusaka peninggalan dan selebihnya sebagai bahan obat yang akan diminta oleh sebagian masyarakat, terutama ibu hamil, ibu yang menyusui dan anakanak. Sementara satok beserta keluarga memasak nasi kuning, lemang dan kenji untuk acara tolak bala besoknya (Abdul Kansas: 2017).

\section{Tradisi Pegi Tepat dalam Konteks Hukum Islam.}

Setelah menguraikan tentang praktek dari tradisi Pegi Tepat yang menjadi kebiasaan masyarakat Talang Petai. Maka dapat dipahami bahwa tradisi yang dilakukan oleh masyarakat tersebut merupakan tradisi yang menyimpang dari ajaran Islam. Hal ini dapat di lihat dari beerapa uraian berikut:

Pertama, keyakinan masyarakat Desa Talang Petai akan kesaktian Puyang Muaro Danau yang bahkan mampu melakukan hal-hal yang luar biasa seperti menjaga anak keturuan meskipun ia sudah meninggal. Dalam Islam, jika seseorang telah meninggal maka ia tidak bisa lagi melakukan aktivitas duniawi. Jika seseorang meninggal, maka ia akan berpindah alam dari alam fana menuju alam barzakh. Maka dalam hal ini, jika seseorang telah meninggal maka ia tidak akan bisa lagi melakukan perbuatan-perbuatan duniawi termasuk melidungi anak keterunannya.

Dalam sebuah hadis disebutkan:

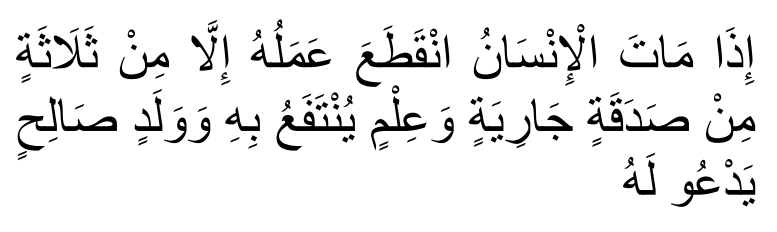

"Jika seseorang meninggal dunia, maka terputuslah amalannya kecuali tiga perkara (yaitu): sedekah jariyah, ilmu yang dimanfaatkan, atau do'a anak yang sholeh" (HR. Muslim)

Di samping itu, yang bisa memberikan manfaat atau mudharat ataupun memberikan perlindungan bagi manusia hanya Allah Swt bukan makhluk. Manusia tidak mampu melakukan apapun yang bisa menjauhkan seseorang dari kemudharatan ataupun untuk mendatangkan kebaikan. Jika seseorang berkeyakinan demikian, maka hal itu bertentangan dengan ketauhidan. Allah Swt berfirman: 


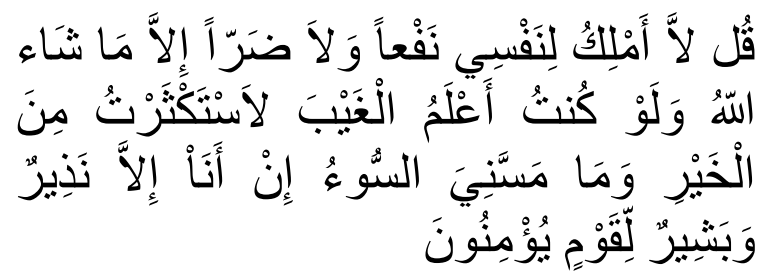

"Katakanlah: "Aku tidak berkuasa menarik kemanfa'atan bagi diriku dan tidak (pula) menolak kemudharatan kecuali yang dikehendaki Allah. Dan sekiranya aku mengetahui yang ghaib, tentulah aku membuat kebajikan sebanyak-banyaknya dan aku tidak akan ditimpa kemudharatan. Aku tidak lain hanyalah pemberi peringatan, dan pembawa berita gembira bagi orangorang yang beriman"." (Q.S. Al-Araf [7]: 188)

Jadi, siapapun orangnya, setinggi apa pun derajatnya, dia tidak akan bisa memberikan manfaat atau mudharat. Apakah itu para malaikat, para nabi, orang-orang shalih, semuanya tidak ada yang bisa memberikan manfaat dan mudharat kecuali Allah Swt.

Kedua, Puyang Muaro Danau memiliki kesaktian yang mampu menyembuhkan orang yang sakit. Pada prinsipnya, manusia tidak akan pernah bisa mengobati sebuah penyakit. Yang mengobati penyakit itu hanyalah Allah Swt seperti doa nabi Ibrahim. Tapi ketika seseorang berkeyakinan bahwa seseorang yang dianggap sakti dapat mengobati orang lain maka hal ini merupakan bentuk kesyirikian.

$$
\text { وَإِذَا مَرِضْتِ فَهُوَ يَثْثْفِينِ }
$$

"Dan apabila aku sakit, Dialah Yang menyembuhkan aku," (QS. al-Syu 'ara': 80).

Dokter ataupun thabib hanyalah wasilah untuk mendapatkan kesembuhan. Akan tetapi, yang memberikan kesembuhan pada penyakit adalah Allah Swt. Jika manusia berkeyakinan bahwa ada orang yang mampu menyembuhkan penyakit maka hal ini merupakan keyakinan yang salah dan menyimpang. Sama artinya ia dengan mempersekutukan Allah Swt dari segi perbuatan-Nya.

Ketiga, masyarakat membuat sesembahan dalam bentuk sesajen. Dalam Islam, membuat sesajen hukumnya haram. Sebab perbuatan tersebut termasuk kepada perbuatan mubazir yang bagian dari perbuatan setan. Sesajen yang dibuat tidak akan dimakan akan tetapi akan dibiarkan terbuang. Allah Swt berfirman:

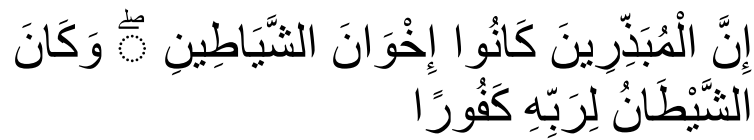

"Sesungguhnya pemboros-pemboros itu adalah saudara-saudara syaitan dan syaitan itu adalah sangat ingkar kepada Tuhannya" (Q.S. Al-Isra [17]: 27).

Keempat, bersujud kepada makam Puyang Muaro Danau. Bersujud kepada selain Allah Swt hukumnya haram dalam Islam. Sujud merupakan bentuk penghambaan diri yang hanya diberikan oleh manusia kepada Allah Swt. Sebab sujud terbut merupakan bentuk ibadah yang dipersembahkan kepada Dzat yang Maha Agung. Jika manusia melakukan sujud kepada selain Allah Swt berarti bisa dipahami bahwa manusia tersebut telah mempersekutukan Allah Swt dalam penyembahan. Seorang muslim mestinya mengesakan Allah Swt dalam 
penyembahan. Hal ini dijelaskan dalam firman Allah Swt:

$$
\text { إِيَّالكَكَ نَعْبُدُ وَإِيَّالَكَ نَسْتَعِينْ }
$$

"Hanya Engkaulah yang kami sembah, dan hanya kepada Engkaulah kami meminta pertolongan" (Q.S. Al-Fatihah [1]: 5).

Kelima, mencampuradukkan agama dengan tradisi. Islam menghargai tradisi yang berlaku pada sebuah masyarakat selamat tradisi tersebut tidak bertentangan dengan nilai-nilai ajaran Islam. Jika seandainya terjadi pertentangan maka nilai-nilai ajaran Islam mesti didahulukan atau ditinggakan. Dalam sebuah hadis dijelaskan:

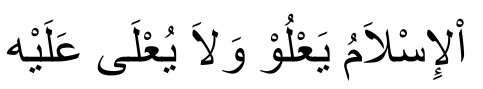

"Islam itu tinggi dan tidak ada yang mengalahkan ketinggiannya" (HR. Daru al-Quthny).

Sebuah tradisi yang dijadikan sebagai salah satu pijakan dalam penetapan hukum dalam Islam adalah tradisi yang tidak bertentangan dengan ajaran Islam. Dalam sebuah kaedah ushul dijelaskan bahwa:

$$
\text { لا عبرة بالعرف إذا خلف الثار ع }
$$

"Tidak ada artinya sebuah tradisi jika seandainya bertentangan dengan alSyari (agama Islam)"

\section{KESIMPULAN}

Tradasi Ziarah kubur merupakan salah satu tradisi yang masih mengakar dan berkembang di tengah-tengah masyarakat. Fenomena ini tidak pernah surut dan kehabisan para penziarah. Meskipun tradasi ziarah kubur ini sangat rawan dengan praktek-praktek syirik, namun masyarakat tetap antusias dalam mengikuti setiap acara yang dilakukan. Praktek ziarah kubur terjadi di seluruh penjuru dunia, dengan motif dan penyajian yang berbeda-beda.

Dalam Syari'at Islam ziarah kubur atau mengunjungi kubur diperbolehkan, bahkan dianjurkan dengan tujuan supaya manusia sadar bahwa kematian akan mendatangi setiap makhluk hidup. Namun, yang tidak diperbolehkan yaitu praktek-praktek di luar ajaran Islam kemudian menjadi bagian dari ziarah kubur dan ditradisikan di tengah-tengah masyarakat.

Dalam Tradisi Pegi Tepat di masyarakat Talang Petai Kabupaten Mukomuko praktek-praktek yang bertentangan dengan syariat Islam seperti:

1. Bersujud ke Kubur/makam, hal ini merupakan syirik yaitu menyembah selain dari Allah SWT.

2. Mempercayai bahwa orang yang sudah meninggal dunia mampu membantu/menolong orang yang masih hidup.

3. Mempercayai nenek moyang (Puyang Muaro Danau) mampu menyembuhkan penyakit.

4. Memeriahkan tempat kuburan nenek moyang.

5. Mencampur adukan antara agama dengan tradisi.

\section{Rekomendasi}

1. Ulama dan tokoh agama perlu mendakwahkan lebih intensif tentang 
larangan tradisi yang mengandung unsur syirik.

2. Pemerintah Daerah harus memfasilitasi diskusi antara masyarakat dengan ulama tentang hukum praktek-praktek Ziarah Kubur.

3. Kaum adat mesti menerima apa yang telah menjadi keputusan ulama tentang praktek ziarah kubur.

4. Peran aktif dari mahasiswa (civitas akademika) dalam merubah pandangan masyarakat setempat tentang praktek ziarah kubur sangat diharapkan

\section{DAFTAR KEPUSTAKAAN}

Albani, Muhammad Nashruddin. 2005. Hukum dan Tata Cara Mengurus Jenazah Menurut Al-Qur'an dan asSunnah, Bogor: Pustaka Imam AsySyafi'i.

Christyawaty, Eny. 2011. Orang Mukomuko di Bengkulu. Padang: Kementerian Kebudayaan dan Pariwisata BPSNT Padang.

Falah, Ahmad. 2012. Spiritualitas Muria: Akomodasi Tradisi dan Wisata. Walisongo: Jurnal Penelitian Sosial Keagamaan, 20(2).

Handayani, Yosi. 2014. Film Dokumenter Wisata Religi Basapa di Ulakan, Kabupaten Padang Pariaman. Desain Komunikasi Visual, 3(1).

Hidayat, Ahmad Taufik dkk. 2013. Tradisi Ziarah di Pariaman Analisis Terhadap Sejarah dan Pemaknaan Ziarah ke Situs
Syekh Burhanuddin. Padang.

Jaiz, Hartono Ahmad dkk. 2011. KuburanKuburan Keramat di Nusantara. Jakarta Timur: Pustaka Al-Kautsar.

Loir, Henri Chambert dan Claude Guilttot. 2010. Ziarah dan Wali di Dunia Islam. Jakarta: Komunitas Bambu.

Mujib, M. Misbahul. 2016. Tradisi Ziarah dalam Masyarakat Jawa: Kontestasi Kesalehan, Identitas Keagamaan dan Komersial. Kebudayaan Islam, 14(2).

Pedawani. 2015. Tradisi Pegi Tepat Masyarakat Desa Talang Petai Kabupaten Mukomuko Bengkulu. IAIN Imam Bonjol Padang.

Purwadi dkk. 2006. Jejak Para Wali dan Ziarah Spiritual. Jakarta: Kompas.

Setiyawan, Agung. 2012. Budaya Lokal dalam Perspektif Agama: Legitimasi Hukum Adat ('Urf) dalam Islam. Esensia, xiii(2).

Subri. 2017. Ziarah Makam Antara Tradisi dan Praktek Kemusyrikan. EDUGAMA, 3(1).

\section{Wawancara}

Abdul Kansas (50 Tahun) kaum adat, wawancara langsung September, 2017

Tipe (70 Tahun) kaum adat, wawancara langsung September, 2017

Abdul Jamar (70 Tahun) kaum adat, wawancara langsung September, 2017 